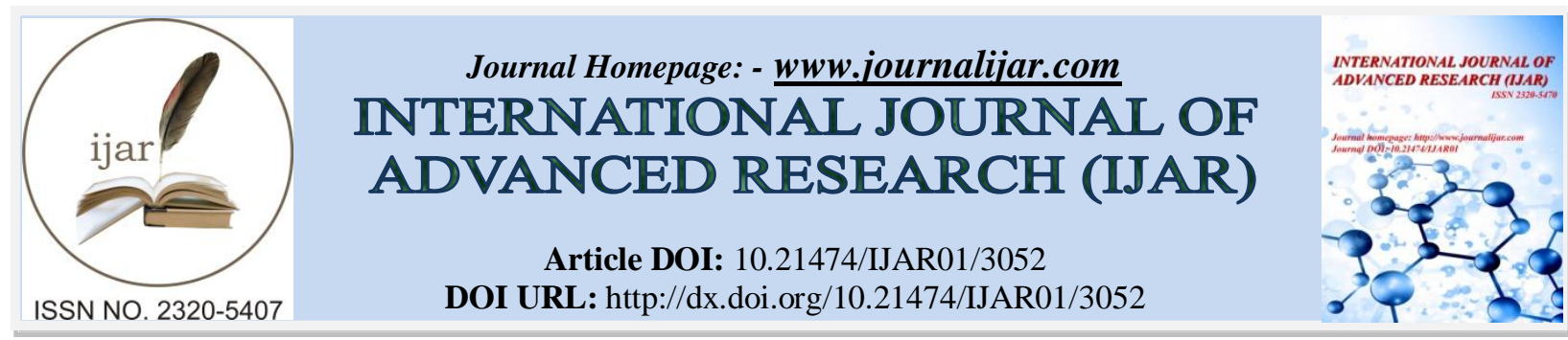

RESEARCH ARTICLE

\title{
EXTRACELLULAR L-ASPARGINASE PRODUCTION BY HALOTOLERANT STRAIN OF ENTEROBACTER HORMAECHEI ISOLATED FROM MARINE FISHES.
}

\author{
${ }^{*}$ Sudha K. ${ }^{1}$, Rani John ${ }^{1}$ and Sivansankari T. R. ${ }^{2}$.
}

1. Department of Biotechnology, St. Peter's College, Kolenchery, Kerala 682311, India.

2. School of Bioengineering, SRM University, Chennai, Tamil Nadu 603203, India.

\section{Manuscript Info}

Manuscript History

Received: 30 November 2016

Final Accepted: 28 December 2016

Published: January 2017

Key words:-

L- Asparginase; Enterobacter

hormaechei; submerged fermentation;

$16 \mathrm{~S}$ rDNA

\begin{abstract}
Bacterial isolates from marine fishes were screened for L-Asparginase production on M9 minimal agar medium. Eleven isolates were selected for the estimation of extracellular enzyme production by submerged fermentation. Highest enzyme activity observed was $39 \mathrm{IU} / \mathrm{ml}$. Bacterial mass assessed as optical density using spectrophotometer showed strong correlation $(\mathrm{p}<0.01)$ with the extracellular enzyme production. In laboratory scale process optimization studies, conditions selected for L-asparaginase production were $40^{\circ} \mathrm{C}$ temperature, $7.0 \mathrm{pH}$ and $3 \%$ sodium chloride concentration. The yield has been increased to 42IU/ml upon fermentation with optimized process parameters. Taxonomic identity of the best extracellular enzyme producing bacterial isolate was studied by biochemical analysis, PCR amplification of a portion of $16 \mathrm{~S}$ rDNA and comparative sequence analysis using NCBI tool. The isolate was identified as Enterobacter hormaechei. Halotolerance and sustained enzyme production at an elevated temperature might be advantages to exploit the bacterium on commercial scale for the production of extracellular L-asparaginase.
\end{abstract}

Copy Right, IJAR, 2016,. All rights reserved.

\section{Introduction:-}

The enzyme L- asparaginase (L- apsarginase amidohydrolase, EC 3.5.1.1) is among the list of essential medicines for basic health system by World Health organization (Robertson et al., 2015; Andrade et al., 2014). L- asparginase is widely accepted for its anti-neoplastic activity and is used for the treatment of acute lymphoblastic leukemia and lymph sarcoma (Neelam and Kuldeep, 2007). L-asparaginase, when administered to patients, catalyzes the hydrolysis of serum L-asparagine into L-aspartic acid and ammonia. Neoplastic cells depend on serum L-aspargine for their survival whereas normal cells can synthesize it. In presence of pharmacological concentrations Lasparaginase, neoplastic cells are eliminated by depriving the essential amino acid. The pharmaceutical enzymes have advantageous characteristics like biodegradability, non-toxic nature and ease of administration at the local sites. Besides the therapeutic value, L-asparaginase has also been used in food processing industries due to their capability to reduce acrylamide content in fried and baked foods.

Various sources of clinically important L-Asparginase enzyme like bacteria, fungi and plants were reviewed by Dhananjayam and Kannan (2014) and Kumar and Verma (2012). Novel sources like marine actinomycetes (Shivasankari et al., 2016) and genetically engineered microorganisms (Kishore et al., 2015) were also studied for

Corresponding Author:- Dr. Sudha K.

Address:- Department of Biotechnology, St. Peter's College, Kolenchery, Kerala 682311, India. 
the enzyme production. Commercial bacterial producers are Erwinea spp., E.coli and Pseudomonas spp. (Peterson and Ciegler, 1969). On long term medication, the enzyme develops adverse immunological reactions (Burke 2014; Cortijo et. al., 2012). There is a continued demand for high quality L-asparaginase with more stable immunological properties for clinical applications. Enzymes from marine organisms, being halotolerant or halophilic in nature, might have more environmental adaptability and stable features. Most of the scientific reports were on cytoplasmic or periplasmic L-Asparginases from bacteria. Considering the advantages of bacterial bioprocess, the present study envisages the screening for halotolerant bacterial strains with extracellular L-asparaginase production. The halophilic nature of the bacteria studied could be an added advantage to eliminate mesophilic contaminants during bioprocess.

\section{Materials and Methods:-}

\subsection{Sample preparation:}

Samples of Sardinella longiceps (common name: Sardine) and Rastrelliger kanagurta (common name: Mackerel) were collected from retail outlets in and around Kochi, Kerala state in South India. A total of 24 samples of fishes were analyzed and each of the samples included a portion of the intestine, gills and skin with muscle.

\subsection{Screening for L-asparginase producing bacteria on M9 medium:}

Screening for L- asparaginase production was carried out on M9 minimal medium (Gulati et al., 1997). Ingredients per litre of the medium are $\mathrm{Na}_{2} \mathrm{HPO}_{4} .2 \mathrm{H}_{2} \mathrm{O}, 6.0 \mathrm{~g} ; \mathrm{KH}_{2} \mathrm{PO}_{4}, 3.0 \mathrm{~g} ; \mathrm{NaCl}, 0.5 \mathrm{~g}$; L-asparagine, $5.0 \mathrm{~g} ; \mathrm{MgSO}_{4} .7 \mathrm{H}_{2} \mathrm{O}$, $0.5 \mathrm{~g} ; \mathrm{CaCl}_{2} .2 \mathrm{H}_{2} \mathrm{O}, 0.15 \mathrm{~g}$; Glucose,2g; bacteriological agar, $20.0 \mathrm{~g}$. Phenol red $(0.005 \%)$ is used as the $\mathrm{pH}$ indicator.

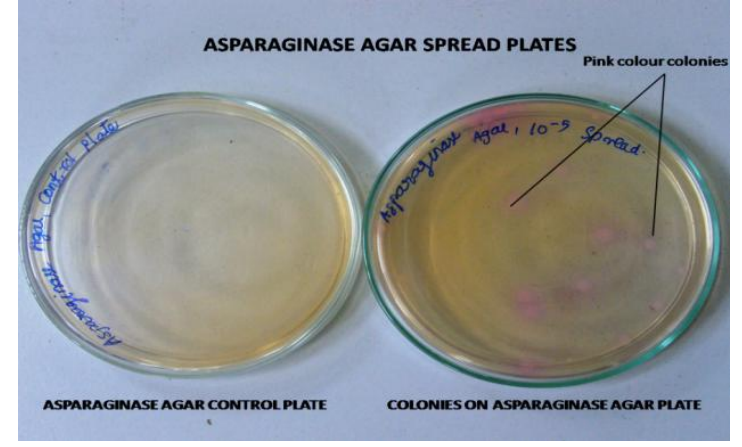

Fig 1:- L-Asparaginase producing colonies showing pink halo in the M9 medium

The M9 agar plates were surface plated with dilutions of the sample. The M9 medium contains L-asparagine as sole source of nitrogen. The pink coloration is due to the increase in $\mathrm{pH}$ around the colonies where ammonia is liberated by the hydrolysis of L-asparagine. Phenol red in the medium indicates the increase in $\mathrm{pH}$ as colour change from yellow to pink and thus suggestive of positive L-asparaginase production. The diameter of the pink zone represents the extent of enzyme production and was measured after $48 \mathrm{~h}$ incubation (Fig 1). Based on the zone diameter, 120 isolates were screened and categorized as 'excellent', 'good', 'medium' and 'poor' producers. The category 'excellent producers' had the diameter of pink halo above 14mm, 'good producers' has the halo between $13.9 \mathrm{~mm}-$ $10 \mathrm{~mm}$, 'medium producers' has $9.9 \mathrm{~mm}-6 \mathrm{~mm}$ and 'poor producers' has lesser than $5.9 \mathrm{~mm}$ respectively.

\subsection{Phenotypic characterization of the $\mathrm{L}$ - asparaginase producing isolates:}

Phenotypic characterization was done by studying morphological and biochemical characteristics. Biochemical tests performed were IMViC tests, sugar fermentation test using glucose, sucrose and lactose, urease test, catalase test, hydrogen sulphide production, gelatin hydrolysis and starch hydrolysis test by standard procedures (Cappuccino and Sherman, 2011; http://microbeonline.com/bacterial-identification-methods/). Growth media used for biochemical studies were supplemented with $3 \%$ sodium chloride to maintain the halotolerant properties of the isolates.

\subsection{Quantitative Assays on the Production of L-asparaginase:}

Broth based assays were performed as an effort to screen the isolate that would produce highest yield of extracellular L-asparaginase. Eleven isolates which produced a conspicuous pink zone with more than $14 \mathrm{~mm}$ diameter size was examined for enzyme activity by submerged fermentation in Tryptone glucose yeast extract (TGY) broth (Gulati et al.,1997; Imada et al., 1973). For enzyme production, a $250 \mathrm{ml}$ volume of TGY broth in $500-\mathrm{ml}$ Erlenmeyer flasks was inoculated $1 \mathrm{ml}$ of inoculum $(0.2 \mathrm{OD}$ at $600 \mathrm{~nm})$ of the bacterium to be tested. The broth is incubated in a shaker incubator at $(180$ rotations $/ \mathrm{min})$ at $37^{\circ} \mathrm{C}$ for $48 \mathrm{~h}$. After incubation, $0.1 \mathrm{ml}$ of 
supernatant was tested with $0.9 \mathrm{ml}$ of $0.1 \mathrm{M}$ Sodium borate buffer $(\mathrm{pH} 8.5)$ and $1 \mathrm{ml}$ of $0.04 \mathrm{M} \mathrm{L}$-asparagine. The mixtures were incubated at $37^{\circ} \mathrm{C}$ for 15 minutes, and the reaction was stopped by the addition of $0.5 \mathrm{ml}$ of $15 \%$ $(\mathrm{w} / \mathrm{v})$ trichloroacetic acid. Precipitated proteins were removed by centrifugation and the liberated ammonia was determined by using Nessler's reagent. Enzyme activity was calculated as international unit (IU) and one unit equals to the amount of enzyme which releases $1 \mu$ mole of ammonia in 1 minute at $37^{\circ} \mathrm{C}$ (Wriston and Yellin,1973).

\subsection{Process optimization studies for L-Asparaginase production:}

Among the eleven isolates, the strain which showed highest enzyme activety ( $\mathrm{Sp} 7)$ was selected for further process optimization. Consistent yield on M9 agar medium as well as TGY broth medium were considered for selecting the candidate strain. The production of the enzyme was evaluated at various $\mathrm{pH}$ ranging from 5 to 9 . The TGY broth was adjusted to the test $\mathrm{pH}$ with $0.1 \mathrm{~N} \mathrm{HCl}$ and $0.1 \mathrm{~N} \mathrm{NaOH}$. TGY broth was supplemented with $3 \% \mathrm{NaCl}$ and the culture was incubated at $37^{\circ} \mathrm{C}$ in shaker incubator. At fixed intervals during incubation, growth at $\mathrm{OD}_{600}$ and the enzyme estimation was done. Optimization of growth temperature was conducted in TGY broths at constant $\mathrm{pH}$ (7) and salt concentration (3\%) at variable temperatures namely $30^{\circ} \mathrm{C}, 37^{\circ} \mathrm{C}, 40^{\circ} \mathrm{C}$ and $45^{\circ} \mathrm{C}$. Similarly, the enzyme production and growth was evaluated at different sodium chloride concentrations like 1\%, 3\%, 5\%, $7 \%$ and $9 \%$ in TGY broth at constant growth temperature $\left(37^{\circ} \mathrm{C}\right)$ and $\mathrm{pH}(7)$.

\subsection{Taxonomic characterization of the isolate by 16SrDNA:}

Genomic DNA was isolated from 18h old cells by the method described by Wilson, 2001[16]. A 380bp stretch of 16S rDNA was amplified in a thermal cycler (Eppendorf, Germanay) using specific forward primer, RW01 (5' -AAC TGG AGG AAG GTG GGG AT-3') and reverse primer, DG74 (5'-AGG AGG TGA TCC AAC CGC A-3'). Polymerase chain reaction (PCR) was carried out using conditions like initial denaturation at $95^{\circ} \mathrm{C}$ for 5 minutes followed by 30 cycles with $95^{\circ} \mathrm{C}$ for 25 seconds for denaturation, $55^{\circ} \mathrm{C}$ for 25 seconds for annealing and $72^{\circ} \mathrm{C}$ for 1 minute for extension and then at $72^{\circ} \mathrm{C}$ for 10 minutes final extension. The amplicons were separated in $1.2 \%$ agarose gel and viewed using gel documentation system (Vilber Loumart, France). The band corresponding to $\sim 380 \mathrm{bp}$ was purified and sequenced in both directions using Genetic Analyzer (Applied Biosystems, USA). The trimmed sequence was used as the query sequence to compare similar sequences using nucleotide BLAST tool from the website of National Centre for Biotechnology Information (NCBI).

\section{Results and Discussion:-}

\subsection{Phenotypic characterization of the $L$ - asparaginase producing isolates:}

Results of the biochemical characterization of L-asparaginase producing bacterial isolates were presented in Table 1. A total of 98 isolates were assigned to different bacterial genera. The prevalence of the genera in the two fishes was Aeromonas (17.34\%), Arthrobacter (4.08\%), Bacillus (8.16\%), Enterobacter (10.20\%), Erwinea (8.16\%) Flavobacter (10.20\%), Pseudomonas (5.10\%), Serratia (14.28\%) and Vibrio (24.48\%). Twenty two isolates could not be assigned to any genera and required further biochemical tests for the identifying the taxonomic status. A few of these bacterial genera are currently exploited for commercial production (Peterson and Ciegler, 1969). Lasparaginase is increasingly in demand due to its specific action and ease in combination therapy. However, on long term usage, the enzyme induces immunological responses like tolerance or hypersensitivity reactions. This warrants the need for novel enzyme with stable properties and fewer immunological effects. In the study, marine bacterial isolates were considered as their enzymes are adapted to specific growth conditions of elevated salt concentrations. Halophilic and halotolerant bacteria were reported to be exploited commercially for pharmaceutical enzyme production (Ebrahiminezhad et al., 2011, Shirazian et al.,2016).

L-Asparaginase is generally a cytoplasmic enzyme or would be secreted into the periplasmic space by the bacteria. Present study attempted to look for the extracellular enzyme production because of the economic benefits of easy downstream processing. Extracellular L-asparaginase production was reported earlier Murthy et al. (2015). The strain selected (Sp7) for the process optimization experiments was a halotolerant bacterium as it did not exhibit growth above $7 \% \mathrm{NaCl}$ concentration in the growth medium. Unlike extreme halophilic bacteria, halotolerant bacteria would not accumulate ions in its cytoplasm for the osmotic balance (Nieto and Vargas, 2002; Brown, 1976). Thus the enzyme would be stable in general physiological conditions and the metabolic properties of the extracellular enzyme might be optimal for the pharmacological purposes.

3.2. Quantitative Assays on the Production of L-asparaginase

Out of the 120 enzyme producing isolates screened on M9 agar, 11 isolates were categorized as 'excellent producers' followed by 34, 48 and 27 as 'good producers', 'medium producers' and 'poor producers' respectively 
(Fig 2). 'Excellent producers' were belonged to the genus Bacillus, Psuedomonas, Aeromonas, Enterobacter, Serratia and Vibrio.

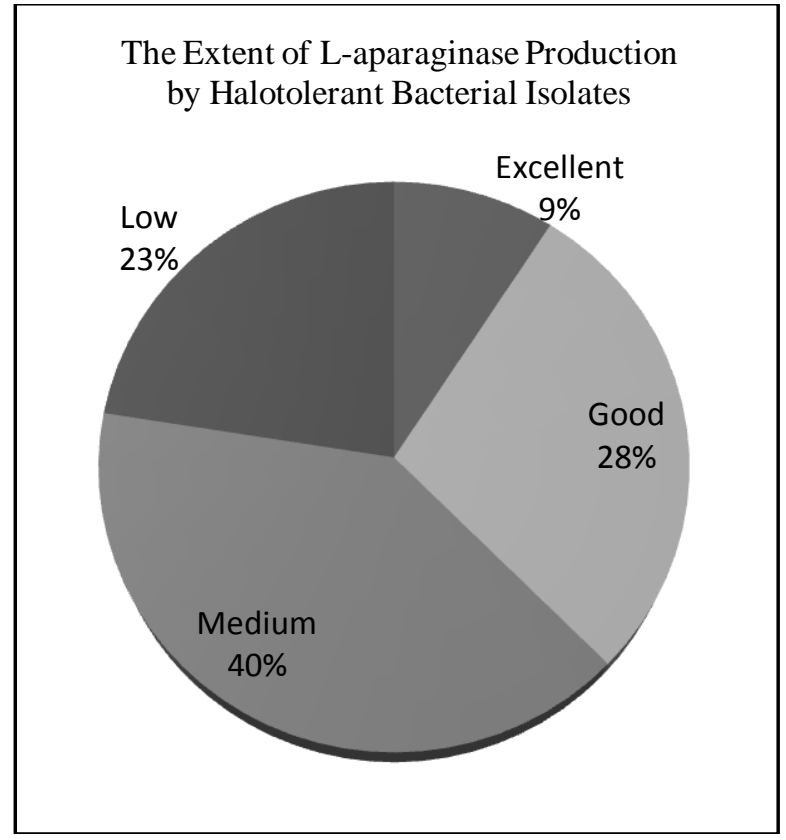

Fig 2:0 L-Asparaginase production by halotolerant bacterial isolates from marine fishes

A total of eleven strains were assessed for their enzyme production in TGY medium by submerged fermentation. Growth conditions provided were $37^{\circ} \mathrm{C}$ temperature, $1 \%$ salt concentration and $7 \mathrm{pH}$. The active enzyme in the culture broth ranged from $11 \mathrm{IU}$ to 39IU per $\mathrm{ml}$. The isolate, $\mathrm{Sp} 7$, showed the highest enzyme activity of 39IU/ml and was selected for further process optimization experiments. The $\mathrm{Sp} 7$ isolate showed $16 \mathrm{~mm}$ pink halo on the M9 agar medium. The bacterium is Gram negative rods, non sporulating and showed positive reaction for biochemical tests like Vogues Proskaeur test, Citrate utilization test, Urease test, Sugar fermentation test for lactose, sucrose and dextrose and Catalase test, and showed negative reactions for Indole test, Methyl red test, Starch hydrolysis test, Gelatin liquefaction test and $\mathrm{H}_{2} \mathrm{~S}$ production test. Phenotypically, the isolate was identified as Enterobacter sp.

\subsection{Process optimization studies:}

Result of the optimization assays for $\mathrm{pH}$, temperature, and salinity tolerance was graphically represented in the fig 3 . In all the experiments growth of the bacterium positively correlated with the extracellular enzyme production $(\mathrm{p}<0.01)$. The parameters selected were $\mathrm{pH} 7$, temperature $40^{\circ} \mathrm{C}$ and salt concentrations $3 \%$ for the laboratory scale production. In optimal physicochemical conditions, the enzyme activity was increased to $42 \mathrm{IU} / \mathrm{ml}$. The increase in production is apparently small (1.6\%) and further studies on substrate optimizations and effective strain improvement strategies are to be performed to increase the yield. Halotolerance and the elevated growth temperature of the isolate could be advantageous for reducing mesophilic contamination during the production process. 

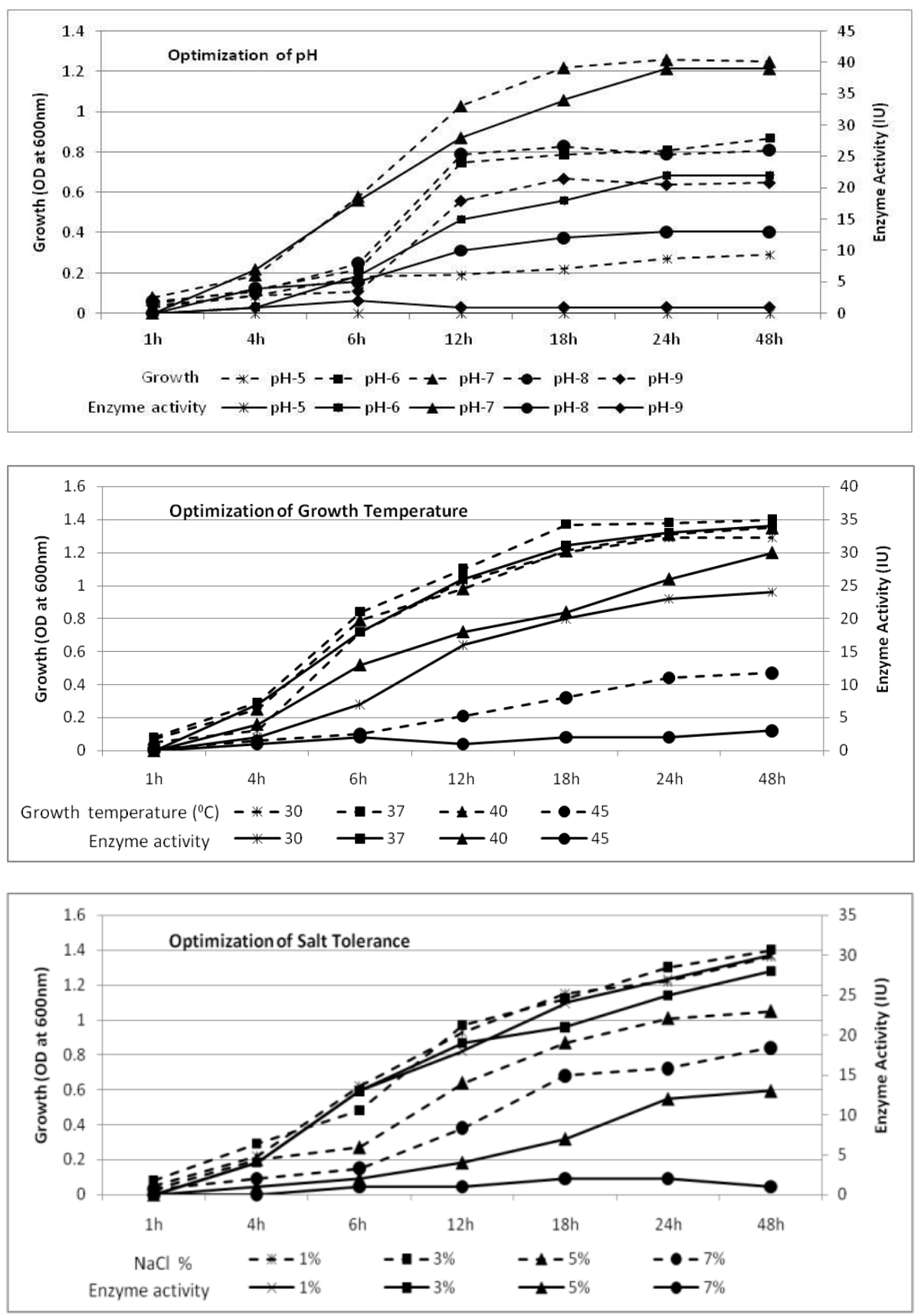

Fig 3:- Effect of $\mathrm{pH}$, temperature, and salt tolerance on growth and L-asparaginase production by Enterobacter sp.(Sp7)

\subsection{Taxonomical analysis of $\mathrm{Sp} 7$ isolate:}

The taxonomic identity of the selected isolate, Enterobacter sp. (Sp7) was further confirmed by16S rDNA characterization. The $16 \mathrm{~S}$ rDNA based identification has advantageous over conventional biochemical method as it provide species level and phylogenetic information (Fredricks and Relman,1996). Fig 3 shows the separated amplicon ( 380bp) in $1.2 \%$ agarose gel. Trimmed sequence data of the partial $16 \mathrm{~S}$ rDNA sequence was used as the query sequence to align similar sequences of the NCBI using nucleotide BLAST tool. The sequence showed $100 \%$ sequence identity with Enterobacter hormaechei. 


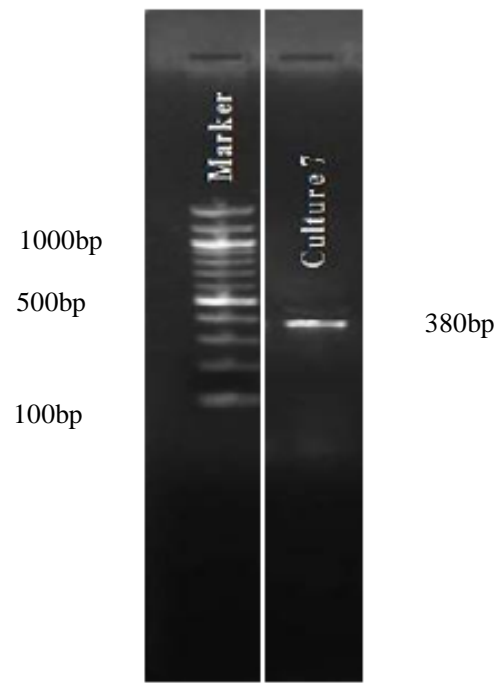

Fig 4:- Partial 16S rDNA amplicon from Enterobacter sp. (Sp7)

Enterobacter hormaechei belong to the family Enterobacteriacae which comprises generally mesophilic bacteria. The species is already exploited for industrial purpose as it produces rhamnolipid with biosurfactant properties (Mojard et al., 2016). In another study by Sullam and his team (2012) on the formation of gut bacterial community on the fish, the halotolerant nature of the bacterium was reported. Enterobacter hormaechei's competent survival efficiency, adaptability to grow in wide range growth parameters and extracellular nature of L-asparginase production would make it a good candidate as an industrial strain with potential for commercial exploitation.

Table.1:- Biochemical characterization of L- asparginase producing bacterial isolates from selected marine fishes.

\begin{tabular}{|l|l|l|l|l|}
\hline \multirow{2}{*}{ Biochemical tests } & \multicolumn{2}{|l|}{$\begin{array}{l}\text { Sardinella longiceps } \\
\text { isolates= } 68)\end{array}$} & \multicolumn{2}{l|}{$\begin{array}{l}\text { Rastrelliger kanagurta (No. of } \\
\text { bacterial isolates = 52) }\end{array}$} \\
\cline { 2 - 5 } & Positive & Negative & Positive & Negative \\
\hline Gram reaction & $14(20.59 \%)$ & $52(79.41 \%)$ & $13(25.00 \%)$ & $39(75.00 \%)$ \\
\hline Citrate utilization test & $40(58.82 \%)$ & $28(41.18 \%)$ & $41(78.84 \%)$ & $11(21.16 \%)$ \\
\hline Indole production test & $32(47.05 \%)$ & $36(52.95 \%)$ & $33(63.46 \%)$ & $19(36.54 \%)$ \\
\hline Methyl red test & $24(35.29 \%)$ & $44(64.71 \%)$ & $21(40.38 \%)$ & $31(59.62 \%)$ \\
\hline Vogues Proskaeur test & $44(64.70 \%)$ & $24(35.30 \%)$ & $30(57.69 \%)$ & $22(42.31 \%)$ \\
\hline Urease test & $41(60.29 \%)$ & $27(39.71 \%)$ & $13(25.00 \%)$ & $39(75.00 \%)$ \\
\hline Lactose fermentation test & $31(45.58 \%)$ & $37(54.42 \%)$ & $34(65.38 \%)$ & $18(34.62 \%)$ \\
\hline Sucrose fermentation test & $28(41.17 \%)$ & $40(58.83 \%)$ & $28(53.84 \%)$ & $24(46.16 \%)$ \\
\hline Dextrose fermentation test & $35(51.47 \%)$ & $33(48.53 \%)$ & $32(61.53 \%)$ & $20(38.47 \%)$ \\
\hline Starch hydrolysis test & $26(38.23 \%)$ & $42(61.77 \%)$ & $9(17.30 \%)$ & $42(82.70 \%)$ \\
\hline Gelatin liquefaction test & $41(60.29 \%)$ & $27(39.71 \%)$ & $31(59.61 \%)$ & $21(40.39 \%)$ \\
\hline Hydrogen sulphide production & $26(38.23 \%)$ & $42(61.77 \%)$ & $12(23.07 \%)$ & $40(76.93 \%)$ \\
\hline Catalase test & $32(47.05 \%)$ & $36(52.95 \%)$ & $23(44.23 \%)$ & $29(55.77 \%)$ \\
\hline
\end{tabular}

\section{Conclusion:-}

A strain of halotolerant bacterium, Enterobacter hormaechei, isolated from marine fish was found to be suitable for extracellular L- Asparginase production. The stability exhibited by the enzyme at wide physico-chemical conditions and tolerance up to $7 \%$ salt concentration would make it a suitable strain for L-asparaginase production with lesser mesophilic contamination.

\section{Declaration of Interest:}

We, the three authors of this article, declare that there is no known conflict of interest associated with this publication. 


\section{Acknowledgements:-}

The authors acknowledge the gratitude to Kerala State Council for Science, Technology and Environment, India, for the financial assistance to conduct the study.

\section{References:-}

1. Andrade, F,A, Borges, K.S. and Silveira, V.S. (2014): Update on the Use of L-Asparaginase in Infants and Adolescent Patients with Acute Lymphoblastic Leukemia. Clinical Medicine Insights, 8: 05-100.

2. Brown, A. (1976): Microbial water stress. Bacteriological Reviews, 40:803-46.

3. Burke, M.J. (2014): How to manage asparaginase hypersensitivity in acute lymphoblastic leukemia, Future Oncol., 10:2615-2627.

4. Cappuccino, J.G., Sherman, N. (2011): (Editors) In Microbiology: A Laboratory manual. $9^{\text {th }}$ Ed. Pearson publishers.

5. Cortijo, C.S., Jimnnez-Cerezo, M.J., Tejada, H.A., (2012): Review of hypersensitivity reactions to antineoplastic agents. Farm. Hosp. 36:148-58.

6. Dhanam Jayam, G., Kannan, S., (2014): The various sources of L-asparaginase International Journal of Recent Scientific Research., 5:342-346.

7. Ebrahiminezhad, A., Rasoul-Amini, S., Ghasemi, Y. (2011): L-Asparaginase production by moderate halophilic bacteria isolated from Maharloo Salt Lake. Indian J. Microbiol.,51: 307-311.

8. Fredricks, D.N., Relman, D.A., (1996): Sequence-based identification of microbial pathogens: A reconsideration of Koch's postulates. Clin. Microbiol. Rev., 9:18-33.

9. Gulati, R., Saxena, R.K., Gupta, R.,(1997): A rapid plate assay for screening L-Asparaginase producing microorganisms. Letters in Applied Microbiology, 24:23-6.

10. http://microbeonline.com/bacterial-identification-methods/ last accessed on 2.12.2016

11. Imada, A., Igarasi, S., Nakahama, K., Isono, M., (1973): Asparaginase and glutaminase activities of microorganisms. J. Gen. Microbiol., 76:85-99.

12. Kishore, V., Nishita, K.P., Manonmani, H.K., (2015): Cloning, expression and characterization of Lasparaginase from Pseudomonas fluorescens for large scale production in E. coli Biotech., 5:975.

13. Kumar, K., Verma, N., (2012): The various sources \& application of L-Asparaginase. Asian Journal of Biochemical and Pharmaceutical Research, 2:197-2015.

14. Mojarad, M., Abbas, A., Golafarin, G., Mohammad, J., (2016): Kerosene biodegradation ability and characterization of bacteria isolated from oil-polluted soil and water. Journal of Environmental Chemical Engineering., (accepted manuscript), http://dx.doi.org/10.1016/j.jece.2016.09.035

15. Moorthy, V., Aishwarya, R., Sumantha, A., Shankaranaya, R.T., (2010): Production, purification and characterization of extracellular L-asparaginase from a soil isolate of Bacillus sp. African Journal of Microbiology Research., 4:1862-1867.

16. Nieto, J., Vargas, C., (2002): Synthesis of osmoprotactants by moderately halophilic bacteria: genetic and applied aspects. Recent Research Development in Microbiology, 6:403-18.

17. Peterson, R.E., and Ciegler, A., (1969): L-Asparaginase production by various bacteria. Applied Microbiology, 17:929-930.

18. Robertson, J., Magrini, N., Barr, R., Forte, G., and Ondari,C., (2015): Special report: Medicines for Cancers in Children: The WHO model for selection of essential medicines. Pediatr. Blood Cancer, 62:1689-1693.

19. Shirazian, P., Asad. S., Amoozegar, M.A., (2016): The potential of halophilic and halotolerant bacteria for the production of anti neoplastic enzymes: L-asparginase and L-glutaminase. EXCLI Journal, 15:268-279.

20. Sivanshankari, T.R., Sudha, K., Bharathi, S., Karthikeyan, V., (2016): Efficacy of plasmid curing agent on Streptomyces longsporesflavns. African Journal of Microbiology Research, 10: 616-625. DOI: 10.5897/AJMR2015.7675.

21. Sullam, K.E., Essinger, S.D., Lozupone, C. A., O’Connor, M.P., Rosen, G.L., Knoght, R., et. al. (2012): Environmental and ecological factors that shape the gut bacterial communities of fish: a meta-analysis. Molecular Ecolog, 21:3363-78.

22. Verma, N., Kumar, K., Kaur, G., Anand, S., (2007): L-asparaginase: a promising chemotherapeutic agent. Crit Rev Biotechnol., 27:45-62.

23. Wilson, K., (2001): Preparation of Genomic DNA from Bacteria. In Current Protocols in Molecular Biology, 00:I:2.4:2.4.1-2.4.5.

24. Wriston, J.C., Yellin, T.O., (1973): L-Asaparginase: A Review. Adv. Enzymol. Relat. Areas Mol. Biol., 39:185248. 